J. Perinat. Med. 14 (1986) 445

\title{
Variability analysis of fetal heart rate signals as obtained from abdominal electrocardiographic recordings
}

\author{
Sergio Cerutti ${ }^{1}$, Giuseppe Baselli ${ }^{1}$, Silvia Civardi ${ }^{1}$, Enrico Ferrazzi ${ }^{2}$, Anna \\ Maria Marconi' ${ }^{2}$, Massimo Pagani $^{3}$, and Giorgio Pardi ${ }^{2}$
}

${ }^{1}$ CNR System Theory Center, Department of Electrical Engineering, Polytechnic of Milan,

${ }^{2} 1^{\text {st }}$ Institute of Obstetrics and Gynecology, University of Milan, and

${ }^{3}$ Department of Medical Pathology, L. Sacco Hospital, University of Milan, Italy

\section{Abdominal ECG lead: detection of maternal and fetal QRS complexes}

The present section describes an algorithm for the digital signal processing aimed at the detection of maternal and fetal QRS complexes from the abdominal ECG lead.

The research described in here is connected to an extensive clinical experience of fetal QRS morphology studies described in [16].

20 healthy pregnant women after the 25 th week of gestation were considered in clinostatic, resting condition at the Department of Obstetrics and Gynecology "L. Mangiagalli", University of Milano.

The processing steps involved are as follows:

1. The original abdominal lead $\mathrm{a}(\mathrm{t})$ is detected via a cardiotocograph HP8030A:

The channel which presents the best characteristics in terms of fetal QRS amplitude and easier recognition (as judged by clinicians) is chosen for the subsequent processing. The signal is recorded on a HP3960A analog recorder and is off-line $A / D$ converted (1 $000 \mathrm{~Hz}$ sampling rate, 12 bit precision) at the Department of Electrical Engineering, Polytechnic in Milano. The digital signal is
Curriculum vitae

SERGIO CERUTTI received his degree in Electronic Engineering in 1971 from the Polytechnic University in Milano, Italy. Actually he is an Associate Professor in Biomedical Engineering at the same University where he does research work in the field of the analysis of biological systems and the related signal processing aspects (ECG, fetal ECG, arterial blood pressure signals in cardiovascular system; analysis of the evoked potentials in the brain by visual stimuli in neuroscience studies). He is a member of IEEE, IEC, IFMBE and other international scientific organizations.

then stored on a DEC-VAX 750 computer for which all processing and graphic programs have been developed.

2. $a(t)$ is then filtered with a derivative and low-pass FIR digital filter (128 coefficients, Weber-Cappellini window, $20 \mathrm{~Hz}$ cutoff frequency). Such a filter accentuates the occurrence of MQRS's, whose maxima are singled out on $\mathrm{a}(\mathrm{t})$. 
3. An averaging is then made, synchronized on MQRS's, using a temporal window which time duration is chosen with respect to the duration of the whole cardiac cycle.

4. A template is obtained as a result of step no. 3 which represents the averaged MQRS along about 280 cardiac cycles.

5. The template, synchronized on MQRS, is subtracted from a $(t)$ signal, using an adaptive gain and without introducing discontinuities: a signal $f(t)$ is hence obtained which contains the information relative only to FECG.

6. The FQRS's are detected by using a filter similar to the one described in step no. 2 having $100 \mathrm{~Hz}$ as its cutoff frequency.

Figure 1 shows an example of this processing: (a) is the original a(t) signal; (b) is the filtered signal (step no. 2); (c) is the $\mathrm{f}(\mathrm{t})$ signal. Note that a good recognition of MQRS's and FQRS's is made even in case of superimposition as indicated with an arrow.

This result is obtained with a template (figure $2 \mathrm{a})$ with a temporal window of $200 \mathrm{~ms}$ before and $450 \mathrm{~ms}$ after the MQRS complex (i. e. approximately one maternal cardiac cycle). The whole MECG may be considerably reduced from the a(t) signal. A successive averaging on $f(t)$ signal synchronized on the maxima of the
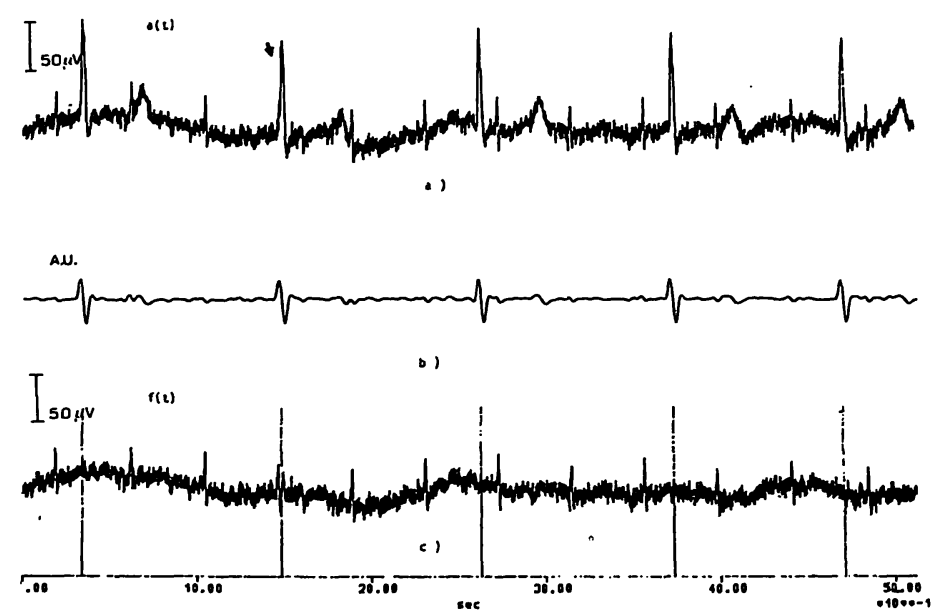

Figure 1. Abdominal ECG lead a(t). A near coincidence of maternal and fetal complexes is indicated by an arrow (a), filtered signal for MQRS recognitions (b), signal $f(t)$. obtained after the subtraction of the maternal template (c). A. U. means arbitrary units.
FQRS's and with a symmetrical temporal window of $400 \mathrm{~ms}$, brings out a mean fetal cardiac cycle, as indicated in figure $2 \mathrm{~b}$. Fetal $P$ wave and QRS complex are clearly visible. The result obtained in figure $2 \mathrm{~b}$ is comparable to the ones obtained through invasive techniques (scalp electrode) [10] or multilead abdominal methods recently introduced in literature [2, 8, 9].

\section{Maternal and fetal heart rate variability sig- nals: auto and cross-spectral analysis}

From the instants of occurrence of MQRS's and FQRS's it is possible to obtain the corresponding heart rate variability (HRV) signals in the form of a LPFES (Low Pass Filtered Event Series) as indicated in figure 3. For a
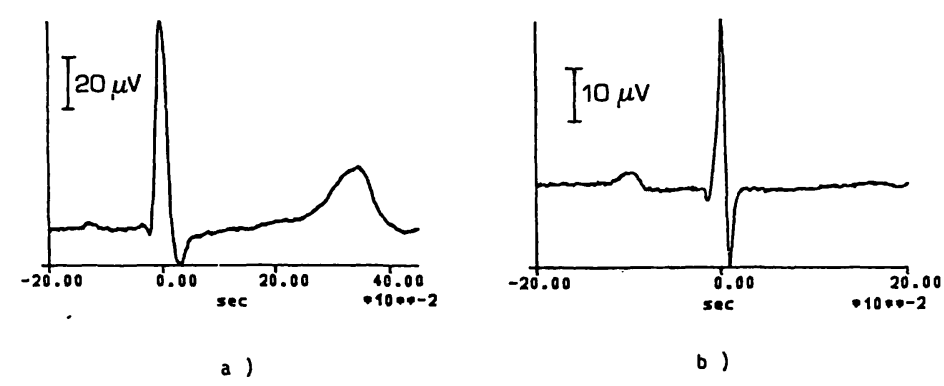

Figure 2. Maternal template (a) and fetal cardiac cycle obtained from a successive averaging of the signal $f(t)$, synchronized with the maxima of FQRS (b).
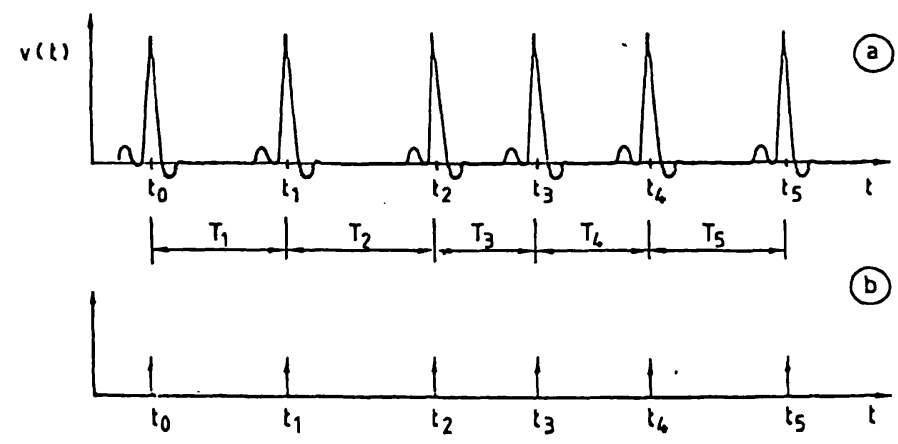

LPFES

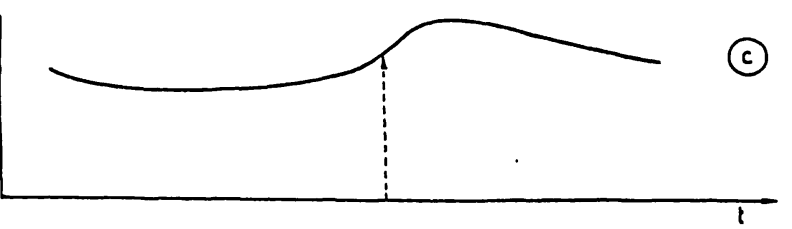

Figure 3. ECG tracing (a), event series representing $\mathbf{R}$ waves (b), Low Pass Filtered Event Series (LPFES) (c) obtained via interpolation of the discrete series constituted by the event series in (b). 
detailed analysis of HRV signals see $[4,5,18]$. LPFES is a continuous time signal obtained via interpolation of the discrete series constituted by the successive $\mathrm{R}-\mathrm{R}$ duration intervals related to each QRS.

The signal is then sampled at $1 \mathrm{~Hz}$, thus respecting the Nyquist frequency.

The frequency analysis of HRV signals is carried out via autoregressive (AR) modelling. The procedure allows to estimate $p$ parameters $a_{k}$ $(k=1,2 \ldots p)$ and the variance of the prediction error $\lambda^{2}$. The correspondent power spectral density $P(f)$ estimation is

$P(f)=\frac{\lambda^{2} \Delta t}{\left|1-\sum_{k=1}^{p} a_{k} \exp (-j 2 \pi k f \Delta t)\right|^{2}}$,

where $\Delta t$ is the sampling period and $\mathrm{f}$ is the frequency.

The autospectra of MHRV signal $\mathbf{P}_{\mathbf{M}}(f)$ and FHRV signal $P_{F}(f)$ are then obtained [11].

A cross-spectral autoregressive bivariate analysis is also implemented in order to evaluate the cross-spectrum $\mathrm{C}_{\mathrm{MF}}(\mathrm{f})$ between maternal and fetal LPFES which is defined as

$C_{M F}(f)=G_{M F}(f) e^{j \varphi_{M F}(f)}$,

where $G_{M F}(f)$ is the amplitude cross spectrum and $\varphi_{M F}(f)$ is the phase spectrum.

The squared coherence is then obtained as

$K_{M F}^{2}(f)=\frac{G_{M F}^{2}(f)}{P_{M}(f) \cdot P_{F}(f)}$,

which is a normalized index of power exchange between the two signals as function of $f$ [13].

\section{Experimental protocol}

20 healthy women are in our study with gestational age between 25 and 40 weeks.

The results presented here refer to a woman at the 39th week (immediately before delivery) and represent the outcome of a preliminary study which confirms the capability of the de- scribed method in giving a quantitative index of the behaviour of fetal and maternal mechanisms of heart rate control during pregnancy.

Applications are foreseen in the diagnostic evaluation of the fetal status in respect to possible maternal pathologies or drug delivery (i. e. atropine) and in the follow-up analysis of the fetus as regards cardiovascular and autonomic nervous system pathologies. Each abdominal ECG tracing is recorded, for at least 20 minutes and stored on an analog tape.

Digital processing of the recorded data for all patients is carried out only over the data relating to a period of about 5 minutes. Two corresponding sequences of equal duration (about 2 minutes) are selected for the successive autoregressive spectral analysis by a visual inspection of the obtained maternal and fetal LPFES's.

The spectra, obtained after removal of the mean value of the signals are considered as representative for the entire period of 5 minutes, since spectra from consecutive records of 2 minutes length give similar results, thus proving the stationarity of the data.

The calculated autospectra are at order $p$ of the autoregressive model which minimizes the Akaike's FPE (Final Prediction Error) figure of merit [11] while, in this preliminary study, we have fixed a priori the order of the autoregressive cross-spectra. Some simulations, carried out on model at different orders, indicate that an order $p=10$ may represent the data at this level of accuracy.

\section{Experimental results}

The heart rate variability signal undoubtedly signifies the behaviour of the heart rate control mechanisms and the influence of the autonomic nervous system which modulates their control loops.

In human adult patients two spontaneous rhythms have been detected in the spectrum of HRV signal: a high frequency oscillation (usually between $0.2 \mathrm{~Hz}$ and $0.35 \mathrm{~Hz}$ ) and a low 
frequency component of $0.1 \mathrm{~Hz}[5,12,15,17$, 18]. The latter of these, also called the $10 \mathrm{~s}$ rhythm, has been considered particularly interesting since it has the same frequency as the well known Mayer waves which have been observed in the blood pressure signal, $[3,6]$, while the former has the same frequency as the respiration signal (the well known respiratory arrhythmia). Both vagal and sympathetic effects might be responsible for the low frequency oscillation while a predominant vagal efferent activity appears to be connected with the high frequency component.

Similar studies performed on dogs, cats, sheep and neonatal lambs $[1,7,19]$ are in agreement with the previously described results and confirm a growing interest in the quantification of these oscillations in terms of the regulating mechanisms of heart rate. Digital signal processing of maternal and fetal heart rate data offers, in our case, a basis for the comprehension of the physiological conditions for both mother and fetus and for the investigation of the complex interactions between them.

In fact, some fast and slow oscillations may be seen in the two signals (see figure 4) and this effect is a proof of the systematic dependence between maternal and fetal mechanisms of

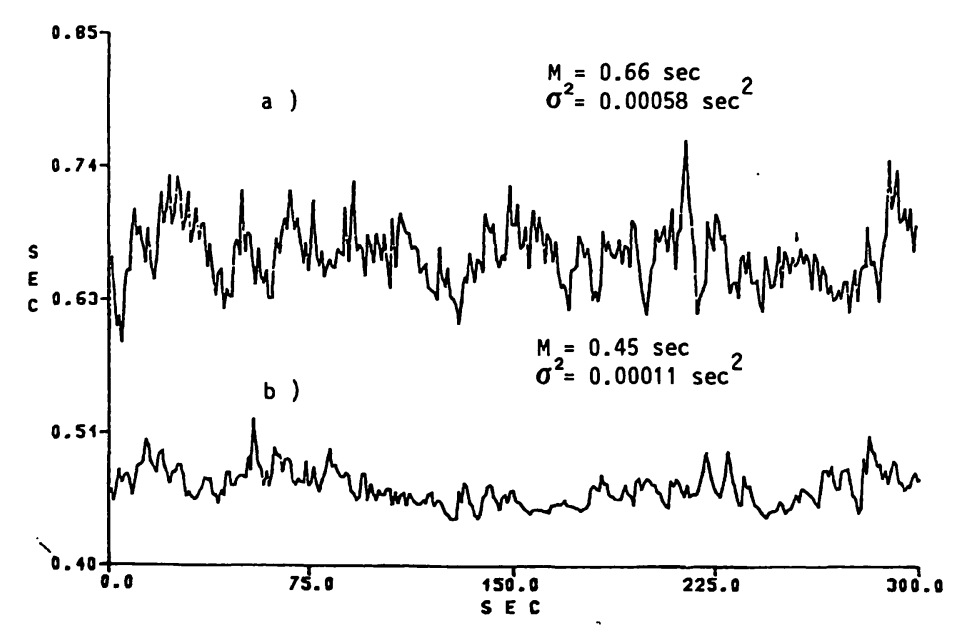

Figure 4. Maternal (a) and fetal (b) LPFES's for a total period of 5 minutes. The horizontal axis indicates the time (s) while the vertical one shows the instantaneous $R-R$ duration after the low pass filtering illustrated in figure $3 \mathrm{c}$.

The mean value $M$ and the variance $\sigma^{2}$ of the two signals are typed in the figure. heart rate control. It is really known that fetal oxygen availability is a function of maternal cardiac output and oxygen saturation, as well as of placental sufficiency, and that a strong reduction in this availability causes accelerations in the fetal heart rate, through the action of the regulatory systems, to assure an adequate oxygen perfusion to the fetus. As a consequence of this dependence, not only placental abnormalities but also changes in maternal conditions (physiological or pathological conditions, infusion of drugs, etc.) should influence the fetal heart rate [14].

The first step in the automatic analysis of the maternal and fetal LPFES is the calculation of the mean values and of the variances of the examined signals (figure 4).

Figure 5 shows the power density spectra obtained from the 2 minute record of the maternal and fetal LPFES previously introduced.

The results indicate clearly two predominant peaks in the maternal spectrum: the first around $0.1 \mathrm{~Hz}$ and the second around $0.33 \mathrm{~Hz}$. The power of the first peak is about $50 \%$ of the total power indicating a marked effect of the $10 \mathrm{~s}$ rhythm while the power of the second one, referring to a respiratory rhythm of about 19 breaths/min, is about $25 \%$ of the total variability of the maternal LPFES. The slow variations in the heart rate signal, having a period which is long in respect to the observation one, are responsible of the amount of power in the spectrum around zero frequency: no information is therefore available in such band using this kind

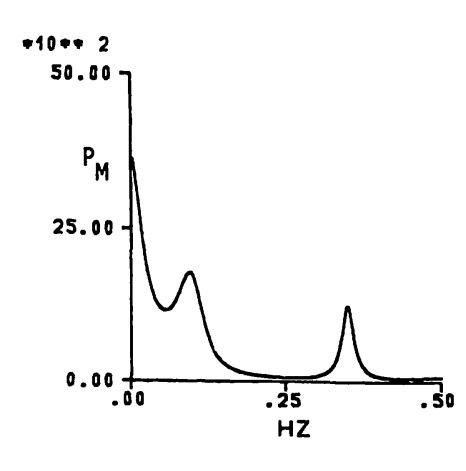

a )

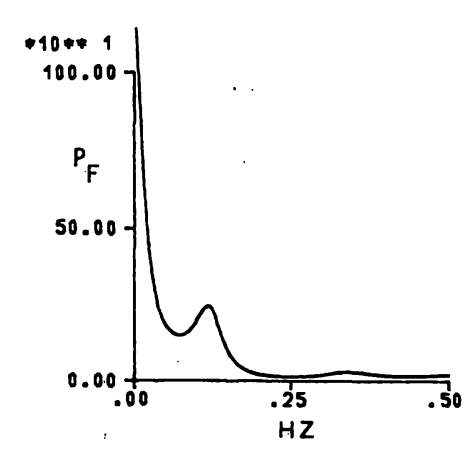

b )
Figure 5. Power spectral density of maternal (a) and fetal (b) LPFES's. 
of analysis. The presence of a component around $0.1 \mathrm{~Hz}$ is clearly evident also in the fetal spectrum indicating the effect of a kind of neural mechanism. It is interesting to note that at the maternal respiration frequency there is a small contribution of power in the fetal spectrum, perhaps signifying a complex interaction between the mother and the fetus caused at that frequency by the maternal breathing.

The cross-spectra analysis on the two LPFES quantifies and correlates the information present in the autospectra analysis: the amplitude cross-spectra $G_{M F}(f)$ between maternal and fetal LPFES (figure $6 \mathrm{a}$ ) points out that a considerable power interchange takes place not only at $0.1 \mathrm{~Hz}$ (clearly visible also in the autospectra) but also around $0.33 \mathrm{~Hz}$. The squared coherence $K_{M F}^{2}(f)$, plotted in the heavy line in figure $6 \mathrm{~b}$, emphasizes that a high degree of correlation exists between the variations of the two signals around $0.1 \mathrm{~Hz}$ and $0.33 \mathrm{~Hz}\left(\mathrm{~K}_{\mathrm{MF}}^{2}(\mathrm{f}) \geq 0.5\right.$ in these two frequency bands). The phase spectrum $\varphi_{\mathrm{MF}}(\mathrm{f})$ indicates the phase difference between maternal and fetal signals: if the coherence is low for a certain frequency range it is known that the phase cannot be estimated reliably in this range. In our case the phase spectrum indicates a positive trend from negative to positive values around $0.1 \mathrm{~Hz}$, while positive values around $150^{\circ}-180^{\circ}$ are prevalent in the high frequency band (MLPFES leads). It is interesting to note that no coherence exists at very low frequencies despite the large contribution of power present in both maternal and fetal LPFES spectra.

\section{Conclusion}

The original algorithm of signal processing illustrated in the present paper allows a reliable

\section{Summary}

The present paper introduces an original method of digital signal processing for an automatic analysis of non-invasive abdominal ECG recordings on pregnant women starting from the 25th week of gestation.

The procedure has been implemented on a DEC-VAX 750 digital computer at the Department of Electrical

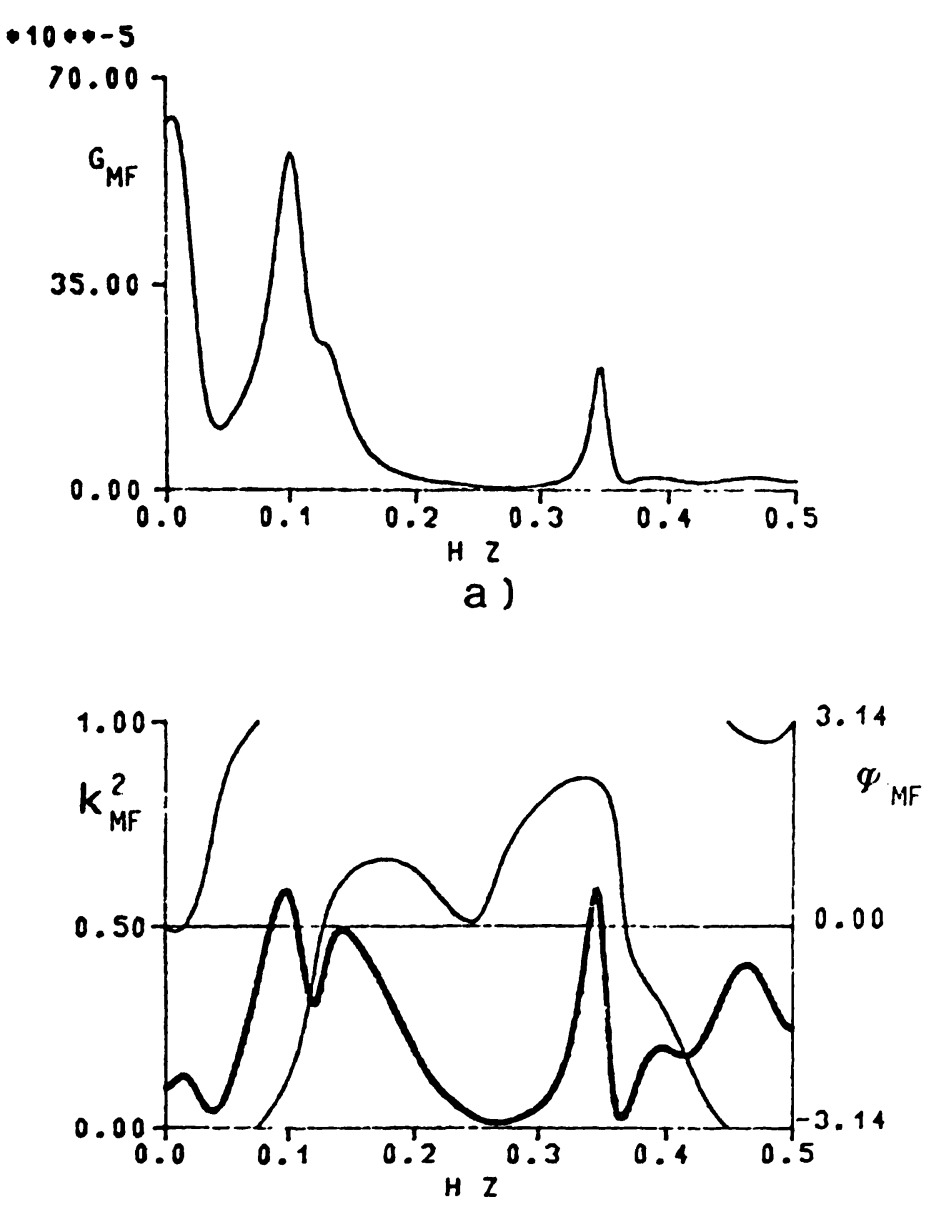

b )

Figure 6. Cross spectral modulus (a), phase spectra $\varphi_{\mathrm{MF}}$ (light line) and squared coherence $\mathrm{K}_{\mathrm{MF}}^{2}$ (heavy line) (b) referred to the signal of figure 4 .

extraction of maternal and fetal QRS's and fetal ECG. The further analysis of HRV signals enhances many information about the linkage between neural control mechanisms of mother and fetus with important impacts both on physiological and clinical side.

The experimental results are obviously still preliminary and necessitate further validation on a wider set of cases.

Engineering, Polytechnic of Milano and the signals are recorded at the Department of Obstetrics and Gynecology "L. Mangiagalli", University of Milano, Italy.

The experimental results presented in here are still preliminary as only few cases have been considered up to now (about 20) and the goal of the paper is mainly 
focused on the algorithmic aspects of the whole procedure implemented in the computer and on the approach of heart rate variability (HRV) signal analysis both in the mother and in the fetus.

Abdominal ECG lead processing is illustrated starting from the step of maternal (M) and fetal (F) QRS recognitions through linear digital filtering (derivative and low-pass FIR filter, Weber-Cappellini window) and weighted averaging techniques synchronized with maternal QRS's.

Figure $1 \mathrm{a}$ shows the original abdominal lead; figure $1 \mathrm{~b}$ the filtered signal for MQRS recognitions; figure $2 \mathrm{a}$ the template of maternal cardiac cycle as obtained after the averaging operation synchronized with the instants of MQRS occurrence. The subtraction of the template results in the abdominal lead shown in figure $1 \mathrm{c}$ in which the contribution of MECG is practically entirely reduced even in the case of MQRS and FQRS overlapping.

An important result is shown in figure $2 \mathrm{~b}$ where the entire fetal cardiac cycle is obtained after a further averaging of the signal shown in figure $1 \mathrm{c}$, with a synchronization on fetal QRS instants of occurrence. Fetal $P$ wave and $Q R S$ complex are clearly visible.

Further analysis is then made of the HRV signals (both maternal and fetal) obtained through low pass filtered event series (LPFES) in correspondence with each QRS occurrence (figure 3). Traditional analysis of HRV signal in the form of mean value and variance are introduced together with the more advanced technique of power spectral density (PSD) estimation, carried out via autoregressive (AR) modelling of the discrete-time samples of HRV signals (figure 4) over a time interval of about
$2 \mathrm{~min}$. The power spectra indicate the two main rhythms which characterize HRV signals.

The first one lies around a frequency of $0.1 \mathrm{~Hz}$ (also called the $10 \mathrm{~s}$ rhythm) and the second one corresponds to respiration rate. Measurements carried out in adult humans connect these rhythms to the behaviour of the autonomic nervous system (ANS) which controls heart rate through sympathetic and parasympathetic efferents $[1,15]$.

Several important observations may be deduced from the analysis of the data shown in figure 5 and figure 6 . The autospectrum of fetal HRV indicates that here the basic $10 \mathrm{~s}$ rhythm exists as well, thus indicating the effect of ANS in mediating sympathetic and parasympathetic drives. Another rhythmic component in the depolarization of the fetal sino-atrial node is also evident (smaller than the previous one) which is synchronous with maternal respiration frequency, thus confirming a complex interaction between a mechanical influence of maternal breathing and a neural reflex in the fetus. A deeper analysis in the cross spectrum (amplitude, phase and coherence spectra) may provide quantitative information about the intimate relationships between the two variability signals.

Applications are foreseen in the physiological studies of the evolution of cardiovascular and neural mechanisms of the fetus, linked to the normal activity of the mother. Clinical implications are also obvious: monitoring of important vital functions of the riskful fetuses starting from an early period of the pregnancy and control of the relevant parameters of mother and fetus during drug delivery or in case of severe pathologies.

Keywords: Abdominal ECG, autoregressive estimation, averaging techniques, digital filtering, fetal ECG, heart rate variability signals, power spectrum analysis, QRS analysis.

\section{Zusammenfassung}

Analyse der fetalen Herzfrequenzvariabilität in abdominalen EKG-Ableitungen

Die vorliegende Arbeit beschreibt eine Originalmethode der digitalen Signalverarbeitung zur automatischen Analyse nicht-invasiver, abdominaler EKG-Aufzeichnungen bei schwangeren Frauen ab der 25. Woche.

Das Verfahren wurde auf einem DEC-VAX 750-Digitalcomputer am Polytechnikum Mailand, Abt. Elektrotechnik, entwickelt. In der Abt. Geburtshilfe und Gynäkologie „L. Mangiagalli“ der Universität Mailand, Italien, erfolgten die EKG-Aufzeichnungen.

Wir stellen hier zunächst einige vorläufige, experimentelle Ergebnisse vor, da bisher nur ca. 20 Fälle vollständig bearbeitet sind. Unser Hauptanliegen ist jedoch, algorithmische Aspekte des gesamten, per Computer durchgeführten Verfahrens zu erläutern und die damit mögliche automatische Analyse der Herzfrequenzvariabilität von Mutter und Fet einzuführen.

Die Verarbeitung des abdominalen EKG's wird bildlich dargestellt: sie beginnt mit der Identifizierung mütterlicher (M) und fetaler (F) QRS-Komplexe durch lineare, digitale Filter und gewichteter, mittelwertbildender Algorithmen in Synchronisation mit maternalen QRSKomplexen.

Abbildung 1 a zeigt die originale, abdominale Ableitung, Abbildung $1 \mathrm{~b}$ das gefilterte Signal zur Erkennung mütterlicher QRS-Komplexe. In Abbildung 2 a sieht man das Templat des maternalen Herzzyklus nach Mittelwertbildung und Synchronisation mit dem Einfall maternaler QRS-Komplexe. Nach Substraktion dieses Templats erhält man die in Abbildung $1 \mathrm{c}$ dargestellte, abdominale Ableitung, in der die mütterliche Komponente fast ganz eliminiert ist, selbst da, wo sich mütterlicher und fetaler Komplex überlappen.

Ein wichtiges Ergebnis wird in Abbildung $2 \mathrm{~b}$ dargestellt: man sieht den gesamten fetalen Herzzyklus nach Bearbeitung des Signals aus Abbildung $1 \mathrm{c}$ und Synchronisation fetaler QRS-Komplexe, wobei P-Welle und QRSKomplexe deutlich sichtbar sind.

Die weitere Analyse sowohl der mütterlichen wie fetalen Herzfrequenzvariabilität erfolgte unter Anwendung spezieller Filtercharakteristika (Abb. 3). Dabei werden so- 
wohl Mittelwert und Varianz berechnet wie auch neuere Techniken eingeführt, nämlich die Beurteilung des Spektrogramms, indem über ein Autoregressionsverfahren zeitlich diskrete Aufnahmen der Herzfrequenzvariabilität über einen Zeitraum von ca. 2 Minuten erfolgen (Abb. 4). Die Spektrogramme weisen 2 Hauptrhythmen auf, die die Variabilität der Herzfrequenzsignale charakterisieren. Der erste liegt mit seiner Frequenz um $0.1 \mathrm{~Hz}$ (er wird daher auch 10-Sekunden-Rhythmus genannt), der zweite Rhythmus korrespondiert mit der Respirationsrate. Untersuchungen an Erwachsenen haben gezeigt, da $\beta$ eine Verbindung zwischen diesen Rhythmen und der Aktivität des autonomen Nervenzentrums besteht, das über sympathische und parasympathische Efferenzen die Herzfrequenz kontrolliert $[1,15]$.

Aus dem Datenmaterial in den Abbildungen 5 und 6 können wichtige Beobachtungen abgeleitet werden.

Das Autospektrum der fetalen Herzfrequenzvariabilität enthält ebenfalls einen 10-Sekunden-Rhythmus, was darauf hinweist, daß das autonome Nervensystem sym- pathische und parasympathische Reize aussendet. Bei der Depolarisation des Sinusknotens ist eine andere, kleinere rhythmische Komponente erkennbar, die eine Synchronisierung mit der mütterlichen Atemfrequenz aufweist. Es muß also eine komplexe Interaktion zwischen dem mechanischen Einfluß der mütterlichen Atmung und dem neuralen Reflex beim Feten bestehen. Eine genauere Analyse des Kreuzspektrums (Amplitude, Phase und Kohärenz) könnte quantitative Informationen über die engen Zusammenhänge zwischen beiden Variabilitätssignalen liefern.

Auf dieser Grundlage sind physiologische Studien zur Entwicklung kardiovaskulärer und neuraler Mechanismen beim Feten in Verbindung mit einer ungestörten mütterlichen Aktivität möglich. Für die klinische Anwendung gilt: wichtige Vitalfunktionen von Risikofeten können bereits ab einem frühen Schwangerschaftsalter überwacht werden und bei medikamentös eingeleiteten Geburten oder schwerer Pathologie ist die Kontrolle relevanter Parameter bezüglich Mutter und Fet möglich.

Schlüsselwörter: Abdominales EKG, Autoregressionsverfahren, digitale Filter, fetales EKG, mittelwertbildende Schaltung, Stromleistungsspektrum, QRS-Analyse, Variabilität von Herzfrequenzsignalen.

\section{Résumé}

Analyse de la variabilité des signaux du rythme cardiaque foetal sur des enregistrements de l'ECG abdominal

Cet article introduit une méthode originale de traitement du signal digital pour l'analyse automatique d'enregistrements non invasifs de l'ECG abdominal chez des femmes enceintes à partir de la 25ème semaine de gestation. Le procédé a été mis en œuvre sur un ordinateur digital DEC-VAX 750 au département de génie électrique de l'école polytechnique de Milan, et les signaux ont été enregistrés dans le département d'obstétrique et de gynécologie «L. Mangiagalli», à l'Université de Milan, en Italie.

Les résultats expérimentaux présentés ici sont encore préliminaires puisque seulement quelques cas ont été menés à bien (environ 20) et le but de cet article est principalement centré sur les aspects algorithmiques de la procédure dans son ensemble traitée par ordinateur et sur l'approche de l'analyse de signal sur la variabilité du rythme cardiaque et chez la mère et chez le fotus.

On illustre le traitement de l'ECG abdominal depuis l'étape de reconnaissance des complexes $Q R S$ de la mère (M) et du fœtus (F) à travers un filtrage digital linéaire (Filtre dérivatif et à faible passage, Weber-Cappellini) et des techniques de moyennage synchronisées avec les complexes QRS maternels.

La figure 1 a montre l'électrode abdominale originale; la figure $1 \mathrm{~b}$ le signal filtré pour la reconnaissance des complexes QRS; la figure 2 a l'aspect du cycle cardiaque maternel obtenu après les opérations de moyennage, synchronisé avec les instants de survenue des MQRS. La soustraction des résultats calibrés au niveau de l'electrode abdominale est montree dans la figure $1 \mathrm{c}$; dans cette figure la contribution du MECG est pratiquement réduite en totalité, même en cas de chevauchement des MQRS et des FQRS. Un résultat important se trouve dans la figure $2 \mathrm{~b}$, figure dans laquelle le cycle cardiaque fotal en totalité est obtenu après un moyennage supplémentaire du signal montré dans la figure $1 \mathrm{c}$, avec une synchronisation avec les instants de survenue des complexes QRS fœtaux. Les ondes $P$ fœtales et les complexes QRS sont nettement visibles.

L'analyse supplémentaire est ensuite effectuee sur les signaux HRV (maternels et fotaux) obtenus par séries de filtration (LPFES) coïncidant avec la survenue de chaque complexe QRS (figure 3). Les analyses traditionelles du signal HRV sous la forme de valeur moyenne et de variance sont introduites ensemble avec la technique la plus avancée d'estimation de la densité spectrale de puissance, menée à bien au moyen d'une modélisation auto-régressive (AR) de fragments temporels des signaux HRV (figure 4) pour un intervalle de temps d'environ $2 \mathrm{~min}$. Le spectre de puissance indique les deux rythmes principaux qui caractérisent les signaux HRV. Le premier avec une fréquence de $0,1 \mathrm{~Hz}$ (on l'appelle également rythme à $10 \mathrm{~s}$ ) et le second correspond au rythme respiratoire. Les mesures réalisées chez des humains adultes connectent ces rythmes au comportement du système nerveux autonome (SNA) qui contrôle la fréquence cardiaque par ses efférences sympathiques et para-sympathiques $[1,15]$.

On peut déduire plusieurs observations importantes de l'analyse des données figurant dans les figures 5 et 6 . L'auto-spectre du HRV fœtal indique qu'ici le rythme basal de $10 \mathrm{~s}$ existe bien, ce qui indique l'effet du SNA avec ses voies de médiation sympathiques et para-sympathiques. Une autre composante rythmique au niveau de 
la dépolarisation du nœud sino-atrial fœtal est aussi évidente (plus petite que la précédente), elle est synchrone avec la fréquence respiratoire maternelle, ainsi est confirmée une interaction complexe entre une influence mécanique de la respiration maternelle et un réflexe nerveux chez le fœtus. Une analyse plus approfondie des spectres de croisement (spectres d'amplitude, de phase et de cohérence) peut fournir des informations quantitatives sur les relations intimes entre les 2 signaux de variabilité.

Mots-clés: Analyse de QRS, analyse du spectre de puissance, ECG abdominal, ECG fœtal, estimation autorégressive, filtrage digital, signaux de variabilité du rythme cardiaque, techniques de moyennage.
On entrevoit des applications pour les études physiologiques de l'évolution des mécanismes cardiovasculaires et nerveux du fotus, liés à l'activité normale de la mère. Les implications cliniques sont également évidentes: surveillance des fonctions vitales importantes des fœtus à risque commençant dès une période précoce de la grossesse et contrôle des paramètres pertinents chez la mère et le fœtus lors des prises médicamenteuses ou en cas de pathologies graves.

\section{References}

[1] Akselrod S, D Gordon, FA Ubel, DC Shannon, AC BARgER, RJ COHEN: Power spectrum analysis of heart rate fluctuation: a quantitative probe of beat-to-beat cardiovascular control. Science 213 (1981) 220

[2] Azevedo S, RL Longini: Abdominal-lead fetal electrocardiographic $R$-wave enhancement for heart rate determination. IEEE Trans Biomed Eng 27 (1980) 255

[3] Baselli G, S Cerutti, S Civardi, F lombardi, A MALLIANI, M PAGANI: Heart rate and arterial blood pressure variability signals for the evaluation of normal and pathological subjects. Proc IEEE Comput in Card Conf, Linköping 1985

[4] Bartoli F, G Baselli, S Cerutti: AR identification and spectral estimate applied to the R-R interval measurements. Int J Biomed Comput 16 (1985) 201

[5] De Boer RW, JM Karemaker, J Strackee: Comparing spectra of a series of point events particularly for heart rate variability data. IEEE Trans Biomed Eng 31 (1984) 384

[6] De Boer RW, JM Karemaker, J StrackeE: Spectral analysis of blood pressure and interval fluctuations. Med Biol Eng Comput 23 (1985) 352

[7] DONCHIN Y, D Caton, SW PoRges: Spectral analysis of fetal heart rate in sheep: The occurrence of respiratory sinus arrhythmia. Am J Obstet Gynecol 148 (1984) 1130

[8] FAVRet AG, AA MARChetTi: Fetal electrocardiograph waveforms from abdominal wall recordings. Am J Obstet Gynecol 27 (1960) 355

[9] FERRARA ER, B WIDRow: Fetal electrocardiogram enhancement by time-sequenced adaptive filtering. IEEE Trans Biomed Eng 29, (1982) 458

[10] HON EH, ST LEE: Averaging techniques in fetal electrocardiography. Med Elec Biol Eng 2 (1964) 71
[11] KAY SM, SL MARPLE: Spectrum analysis: a modern perspective. Proc IEEE 69 (1981) 1380

[12] KITNEY RI, O RoMPELMAN: The study of heart rate variability. Clarendon Press, Oxford 1980

[13] Morf M, A VIEIRA, DTL LEE, T KaIlath: Recursive multichannel maximum entropy spectral estimation. IEEE Trans GE-16 (1978) 85

[14] NAGEL JH: Progresses in fetal monitoring by improved data acquisition. IEEE Eng Med Biol Magazine, Perinatal Monitoring 3 (1984) 9

[15] Pagani M, F Lombardi, S Guzzetti, G Sandrone, O Rimoldi, G Malfatto, S Cerutti, A Malliani: Power spectral density of heart rate variability as an index of sympatho-vagal interaction in normal and hypertensive subjects. J Hypertension 2 (1984) 383

[16] Pardi G, E Ferrazzi, I Cetin, S Rampello, G Baselli, S Cerutti, S Civardi: The clinical relevance of abdominal fetal electrocardiogram. J Perinat Med, this issue, pp 371

[17] Pomeranz B, RJB Macaulay, MA Caudill, I Kutz, D Adam, D Gordon, KM Kilborn, AC Barger, DC Shannon, RJ CoHEN, H Benson: Assessment of autonomic function in humans by heart rate spectral analysis. Am J Physiol 248 (1985) H 151

[18] SAYERS B MCA: Analysis of heart rate variability. Ergonomics 16 (1973) 85

[19] SuMIS AS, RT OJA, IA VÄLIMÄKr: Should heart-rate variability be computed using heart-beat interval or heart-rate scale? Comparison of data during autonomic blockade in neonatal lambs. Proc XIV Int Conf Med Biol Eng, Helsinki 1985

Prof. Sergio Cerutti

Polytechnic, Department of Electronics Piazza Leonardo da Vinci, 32 20133 Milano, Italy 